ORIGINAL

\title{
DETERMINATION OF METALLOTHIONEIN LEVELS IN TISSUES OF YOUNG RATS FED ZINC-ENRICHED DIETS
}

\section{DETERMINAÇÃO DOS NÍVEIS DE METALOTIONEÍNAS EM TECIDOS DE RATOS JOVENS ALIMENTADOS COM DIETAS ENRIQUECIDAS COM ZINCO}

\author{
Gilberto Simeone HENRIQUES 1 \\ Silvia Maria Franciscato COZZOLINO'
}

\begin{abstract}
The objective of this work was to quantify metallothioneins (MT's) in tissues of rats fed different concentrations of zinc, in order to observe the animal response to the metal in relation to different types of diets, and to assess the nutritional status relating to zinc in the diets. Thirty-two Wistar newly-weaned male rats were distributed into four experimental groups and housed in individual cages. They had free access to water and diet containing different zinc concentrations, named RC (AIN 93-like diet), RH (customary diet of the university restaurant), both non-supplemented, and RCS and RHS, supplemented. After four weeks, the animals were killed and liver, kidneys, femurs and testes were isolated to determine metallothionein levels by a $\mathrm{Cd} / \mathrm{Hb}$ affinity assay. Zinc content was determined by Flame Atomic Absorption Spectroscopy (FAAS). The results showed that zinc supplementation produced no change in the tissue metallothionein profile in the doses under analysis. The highest metallothionein mean concentration was found in the liver - 36.21 $\pm 0.88 \mu \mathrm{g} / \mathrm{g}$ (mean for RC-RCS groups), and $28.92 \pm 5.32 \mu \mathrm{g} / \mathrm{g}$ (mean for RH-RHS groups). Metallothionein concentrations in testes were quite high, considering the small volume of the organ - $19.29 \pm 0.54 \mu \mathrm{g} / \mathrm{g}$ (mean for RC-RCS groups), and $17.22 \pm 1.07 \mu \mathrm{g} / \mathrm{g}$ (mean for RH-RHS groups). Significant increases in zinc concentration were observed in the liver of young supplemented rats - 38.94 $\pm 3.43 \mu \mathrm{g} / \mathrm{g}$ of tissue for RCS, and $42.83 \pm 2.78 \mu \mathrm{g} / \mathrm{g}$ of tissue for RHS, and in the femurs $-140.04 \pm 6.03 \mu \mathrm{g} / \mathrm{g}$ of tissue for RCS, and $86.57 \pm 6.95 \mu \mathrm{g} / \mathrm{g}$ of tissue for RHS. The different carrying zinc food matrices caused no change in the adaptive response to metallothionein metabolism, and the lack of responsiveness towards metallothionein synthesis did not invalidate the results of tissue zinc concentration parameters, which suggest different degrees for zinc bioavailability.
\end{abstract}

Index terms: metallothionein, zinc, biological availability, experimental diets.

RESUMO

O objetivo deste trabalho foi quantificar metalotioneínas (MT's) em tecidos de ratos alimentados com diferentes concentrações de zinco, a fim de observar a resposta dos animais ao metal em relação a diferentes tipos de ração e checar se esta medida poderia ser utilizada como parâmetro para avaliar o estado nutricional relativo ao zinco. Trinta e dois ratos machos Wistar, recém desmamados, foram distribuídos em 4 grupos experimentais, acondicionados em gaiolas individuais, com livre acesso à água desmineralizada e às rações com diferentes concentrações de zinco, chamadas $R C$ (dieta semelhante à AlN93) e $R H$ (dieta habitual do restaurante

\footnotetext{
(1) Faculdade de Ciências Farmacêuticas, Universidade de São Paulo, Av. Professor Lineu Prestes, 580, Bloco 14, 05315-970, São Paulo, SP, Brasil, Correspondence to Correspondência para: S.M.F.COZZOLINO. E-mail:smfcozzo@usp.br
} 


\begin{abstract}
universitário), ambas não suplementadas, e RCS e RHS, seus pares suplementados. Após 4 semanas, os animais foram sacrificados e o fígado, os rins, os fêmures e os testículos foram isolados para determinar-se as concentrações de metalotioneínas por meio de um ensaio de afinidade $\mathrm{Cd} / \mathrm{Hb}$. O conteúdo de zinco foi determinado por espectroscopia de absorção atômica de chama. Os resultados mostraram que a suplementação com zinco não produziu mudanças no perfil de metalotioneínas dos tecidos a partir das doses administradas. As concentrações médias mais elevadas foram encontradas no fígado, $36,21 \pm 0,88 \mu \mathrm{g} / \mathrm{g}$ (média para os grupos $R C$ e RCS) e 28,92 $\pm 5,32 \mu \mathrm{g} / \mathrm{g}$ (média para os grupos RH e RHS). As concentrações de metalotioneína nos testículos foram significativamente altas, considerando o pequeno volume do órgão - 19,29 0,54 $\mu \mathrm{g} / \mathrm{g}$ (média para os grupos $R C$ e RCS) e 17,22 $\pm 1,07 \mu \mathrm{g} / \mathrm{g}$ (média para os grupos $R H$ e RHS). Aumentos significativos nas concentrações de zinco foram observados nos fígados de animais jovens suplementados com o metal, 38,94 $\pm 3,43 \mu \mathrm{g} / \mathrm{g}$ de tecido para RCS e 42,83 $\pm 2,78 \mu \mathrm{g} / \mathrm{g}$ de tecido para RHS, e nos fêmures, $140,04 \pm 6,03 \mu \mathrm{g} / \mathrm{g}$ de tecido para $R C S$ e 86,57 $\pm 6,95 \mathrm{mg} / \mathrm{g}$ de tecido para RHS. As diferentes matrizes alimentares pelas quais o zinco foi veiculado não provocaram mudanças na resposta metabólica adaptativa de metalotioneínas e a ausência de responsividade na síntese de metalotioneínas neste trabalho não invalida os resultados dos parâmetros de concentração de zinco, que sugerem diferentes graus de biodisponibilidade do metal.
\end{abstract}

Termos de indexação: metalotioneína, zinco, disponibilidade biológica.

\section{INTRODUCTION}

Zinc $(\mathrm{Zn})$ is undoubtedly one of the most important transition metals in mammalian organisms, ranking second as the most abundant. The binding of zinc to biological molecules is fundamental to the action of at least 50 different types of enzymes from many different classes such as oxyreductases, transferases, hydrolyses, lyases, isomerases and ligases (Valee \& Falchuk 1993).

From a bioinorganic-chemical point of view, investigations on $\mathrm{Zn}$ binding to organic-biological molecules such as metallothioneins, insulin, and transcription factors, have improved the knowledge on metal-ligand interactions and on the consequences to the biological systems in which they take part (Vallee et al., 1991; Valles Mota et al., 2000).

As a result, the first study developed under this approach focused on the sites of absorption for metals, such as zinc $(\mathrm{Zn})$ and copper $(\mathrm{Cu})$, the participation of metallothionein as a ligand, and, consequently, the induction of synthesis by the metals (Hoadley et al., 1987).

Metallothioneins have been extensively isolated and characterized in liver and kidneys of several species (Ripa \& Ripa, 1999). The induction of metallothioneins by essential metals or other induction agents is the central goal of several studies (Bremner \& Beattie 1990; Cai et al., 1999; Jacob et al., 1999). Nevertheless, few of them use the feed plus the essential mineral as a carrier for supplementation (Reeves, 1995; Tran et al., 1999).

The food composition of diets regularly consumed by the population has not been stressed as important, despite the fact that the components not rarely show dynamic interactions which can influence metal bioavailability.

Zinc (Zn) concentrations in liver, kidneys and testes, tissues recognized as important for the metal metabolism, give the required information to assess the nutritional status of the element (Cozzolino1997). Moreover, analyses of metallothioneins in the tissues may represent a very important biochemical factor for correlation, that is, the comparison of the results would be significant in relation to understanding zinc homeostasis and bioavailability (Lau \& Cherian, 1999, Cai et al., 2000; Chmielnicka \& Sowa, 2000).

The purpose of this study was to assess the response attained by different concentrations of oral zinc supplementation carried by diets prepared with the food customarily consumed by the population in parallel to the standard feed for growing rats, on metallothionein levels as a zinc bioavailability parameter, in tissues of young rats.

\section{MATERIAL AND METHODS}

The first step was to prepare a feed according to the American Institute of Nutrition recommendations for growing rats, AIN 93G (Reeves \& Rossow 1993), named RC (AIN 93G-like diet, non-supplemented), and RCS (AIN 93G-like diet, supplemented with zinc). The components of the diets were purchased individually in pre-mixtures as follows - salt, vitamins, casein P.A., choline bitartrate (Rhoster Ind. and Com. Ltd., São Paulo, SP), starch and maltodextrin (Food Technology Department Federal University of Viçosa, Viçosa, MG, Brazil). The components were mixed in a blade stainless steel-lined homogenizer. Concomitantly, samples of the diet customarily consumed in the main restaurant from the campus of the University of São Paulo were collected. Each pre-cooked different food sample was placed in separate stainless steel ashtrays, dried in a ventilated oven at $60^{\circ} \mathrm{C}$, powdered in a knife-mill, and homogenized in a blade blender. The diets were stored in sealed plastic bags and refrigerated at a temperature between 4 and $8^{\circ} \mathrm{C}$ for further analysis of main components. After the addition of zinc, the diets were named $\mathrm{RH}$ (customary diet from the main restaurant of the university, non-supplemented), and RHS (customary diet from the main restaurant of the university, supplemented with zinc). 


\section{Zinc $(\mathrm{Zn})$ and Copper $(\mathrm{Cu})$ Determinations}

The amounts of zinc and copper in diets and animal tissues were quantified by flame atomic absorption spectrophotometry (Hitachi Z-5000, Hitachi Ltd, Japan) by direct sample reading, after wet via oxidation at $250^{\circ} \mathrm{C}$ in a closed microwave system (CEM- MDS 2000, CEM Corp., USA). A standard reference sample from the BCR 185 Community Bureau of Reference was used in all measurements to determine the accuracy of the proceeding.

\section{Supplementation of the diets}

Both diets were supplemented with twice the concentrations obtained in the spectrophotometric analyses for zinc and copper (Table 1). For this, zinc carbonate was used $\left(3 \mathrm{Zn}(\mathrm{OH})_{2} .2 \mathrm{ZnCO}_{3}\right.$ Carlo Erba, zinc content of $59.41 \%)$. The amounts calculated to attain the double of zinc concentrations in each diet were $450 \mathrm{mg}$ of $\mathrm{ZnCO}_{3}$, to the AIN 93G-like diet (RCS), and $250 \mathrm{mg}$ to the diet of the restaurant (RHS).

\section{Biological assay}

Thirty two male albino Wistar rats (Rattus norvegicus), newly-weaned, were precisely weighed and distributed in four groups of eight animals each, under the criteria of limit intragroup weight variation of less than 10 $\mathrm{g}$, and intergroup of less than $5 \mathrm{~g}$. The rats were housed in stainless steel cages, submitted to an adaptive diet, AIN 93G-like, contraining $46.26 \mathrm{mg}$ of zinc/ $\mathrm{kg}$ of diet, for 24 hours. Each group was subsequently fed with one of the four types of diet available (Tables 1 and 2), containing different zinc and copper concentrations. Water, treated by an ELIX-RiOS ${ }^{\circledR}$ electrodeionisation system and reverse osmosis, in 10-15 M. $\Omega \mathrm{cm}$ of resistivity, presenting undetectable concentrations of zinc and copper, and diet were offered ad libitum and replaced every two days.

The animals were weighed weekly, at the same hour. Temperature and humidity were kept constant. A light control made feasible a 12-hour shift of light and dark in the room. Routine hygiene cares were performed, including the cleaning of cages with demineralized water, whenever necessary, to clean off urine residues. After 29 days, the offer of diet was discontinued and the animals fasted for 12 hours. Water was offered ad libitum. The animals were then killed by a trained assistant through cervical dislocation without anesthetics, to avoid any interference in the assay. Liver, kidneys, testes and femurs were isolated, weighed and divided into two parts. Half of each was immediately packed and frozen at $-70^{\circ} \mathrm{C}$ for further mineral analyses, by atomic absorption spectrophotometry. Except for femur samples, the remaining halves were immersed in Tris- $\mathrm{HCl}$ buffer, $\mathrm{pH} 7.4$, at $8^{\circ} \mathrm{C}$, and processed within 24 hours at most.

\section{Experimental Proceedings}

The tissues were washed in iced Tris-HCl buffer, $\mathrm{pH} 7.4$, homogenized in glass tubes with two parts of buffer by a Potter-Helvjein device provided with Teflon ${ }^{\circledR}$ pestle. Homogenates were centrifuged at $10.000 \mathrm{~g}$ for $10 \mathrm{~min}$; the upper portions were removed and placed in a boiling bath $\left(100^{\circ} \mathrm{C}\right)$. After heating, samples were re-centrifuged at $10.000 \mathrm{~g}$ for $2 \mathrm{~min}$, in order to remove the precipitated proteins. The upper portions were transferred to two $1.5 \mathrm{ml}$ glass tubes, and stored at $-70^{\circ} \mathrm{C}$ until further analyses.

\section{Determination of Metallothioneins}

In order to quantify concentration and total amount of metallothioneins in the animal tissues, an affinity assay for cadmium-hemoglobin was used, following the proceedings recommended by Eaton \& Cherian (1991): (1) in centrifuge tubes, $200 \mathrm{~mL}$ of a solution of ${ }^{109} \mathrm{Cd}$ (2 $\mathrm{mg} / \mathrm{mL}, 1 \mathrm{~mL} / \mathrm{mL}$, Amersham International, Buckinghamshire, England) were incubated with $200 \mu \mathrm{L}$ of centrifuged tissues, for $10 \mathrm{~min}$ at environmental temperature; (2) $100 \mu \mathrm{L}$ of a $2 \%$ solution of bovine hemoglobin were added, homogenized, and heated $\left(100^{\circ} \mathrm{C}\right)$ in boiling bath for 2 minutes; (3) tubes were placed in an ice bath. After cooling, samples were centrifuged at $10000 \mathrm{~g}$ for $2 \mathrm{~min}$, in a cooler microcentrifuge (Beckman ${ }^{\circledR}$; (4) after transferring the upper fraction, another $100 \mu \mathrm{L}$ of $2 \%$ hemoglobin were added to the fraction and steps (2) and (3) were repeated; (5) a $300 \mu \mathrm{L}$ fraction of the upper portion was carefully taken, without any track of precipitate, and transferred to clean $\boldsymbol{\gamma}$-counting glass vials; (6) radioactivity was determined in the upper fraction by direct counting in a $\gamma$-spectrometer; (7) vials containing Tris-HCl buffer in the place of tissues, as blank, and vials with ${ }^{109} \mathrm{Cd}$ standard solution for total radioactivity $(200 \mu \mathrm{L}$ of Tris- $\mathrm{HCl}$ buffer in the place of hemoglobin) were concomitantly counted in each assay.

\section{Statistical Analyses}

The analyses were performed with Estatística ${ }^{\circledR}$ v.5. software. The total data variation, in each group, was decomposed according to ANOVA one-way method. Averages were compared according to Tuckey test. The Levene test was carried out to assess the homocedasticity of samples. Multiple linear correlation was established through the minimum squared method and level of significance established as 5\%.

\section{RESULTS AND DISCUSSION}

Tables 1 and 2 present the results of chemical composition of the diets. Data analyses show homogeneity among macronutrient quantities in the diets with the same basic composition.

The ANOVA one-way analysis was applied to 
Table 1. Macronutrients composition (\%) and zinc ( $\mathrm{Zn}$ ) and copper $(\mathrm{Cu})$ contents of the AIN-93G like diets (RC and RCS used in biological assay ${ }^{1,2}$.

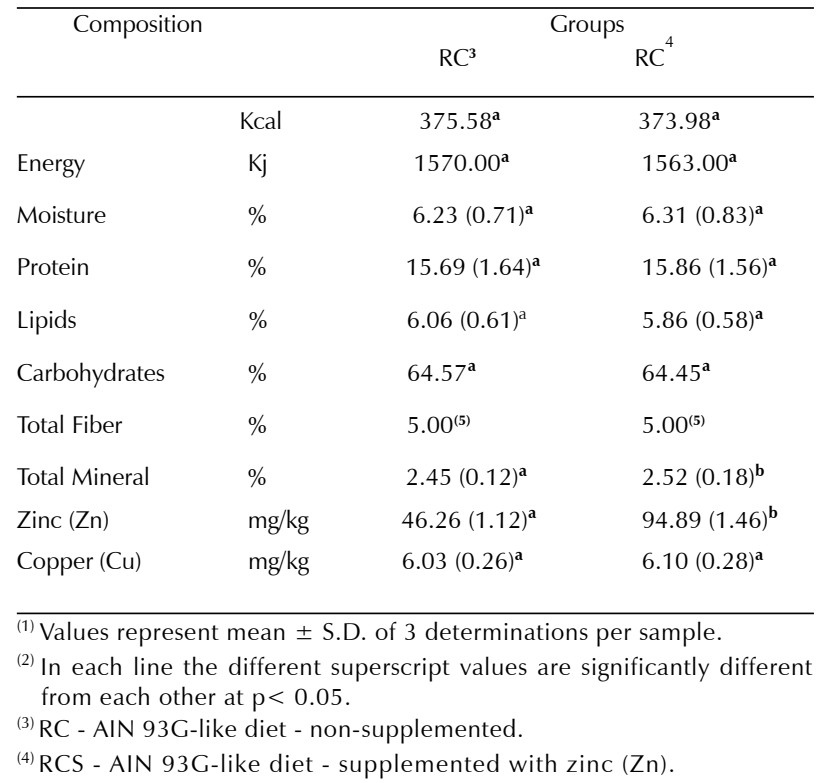

groups of results; therefore, all comparisons were made between RC and RCS, and between RH and RHS. Whenever necessary, the effects between groups of results under analyses were cut off in order to improve the contrast between averages.

Weight gain for RC and RCS groups were $173.67 \pm 16.71 \mathrm{~g}$ and $176.06 \pm 15.08 \mathrm{~g}$, respectively. For $\mathrm{RH}$ and RHS, the results were $134.88 \pm 17.24 \mathrm{~g}$ and $123.50 \pm 7.80 \mathrm{~g}$. Non-significant differences were found in weight gain between groups RC and RCS, and between $\mathrm{RH}$ and RHS ( $\mathrm{p}>0.05)$.

Total diet consumption was the same for the two groups under comparison. Groups RC and RCS consumed an average of $15.10 \pm 0.16 \mathrm{~g}$ of diet per day, total consumption of $449.79 \pm 30.66 \mathrm{~g}$ and $459.49 \pm 21.74 \mathrm{~g}$, respectively.

Averages for groups $\mathrm{RH}$ and RHS were $13.4 \pm 0.62 \mathrm{~g}$ per day, total consumption of $388.96 \pm 37.64 \mathrm{~g}$ and $415.09 \pm 35.08 \mathrm{~g}$, respectively. Zinc intake showed values similar to that expected at experimental design. RCS zinc consumption $(43.60 \pm 2.06 \mu \mathrm{g}$ of $\mathrm{Zn})$ was approximately twice as high as that for RC (20.81 $\pm 1.42 \mathrm{mg}$ of $\mathrm{Zn})$, whereas RHS consumed 2.5 times more zinc $(25.21 \pm 2.35 \mu \mathrm{g})$ than $\mathrm{RH}(10.22 \pm 0.99 \mu \mathrm{g})$. In both cases, zinc consumption variations were significantly different $(p<0.01)$. Copper consumption showed the same proportion as that observed for the element in diet composition. Groups RC and RCS consumed around three times more copper $(2.71 \pm 0.18 \mu \mathrm{g}$ of $\mathrm{Cu})$ and $(2.80 \pm 0.13 \mu \mathrm{g}$ of $\mathrm{Cu})$, respectively, than $\mathrm{RH}(0.92 \pm 0.09 \mu \mathrm{g}$ of $\mathrm{Cu})$ and $\mathrm{RHS}$ $(0.91 \pm 0.08 \mu \mathrm{g}$ of $\mathrm{Cu})$.
Table 2. Macronutrients composition (\%) and zinc ( $\mathrm{Zn}$ ) and copper (Cu) contents of the customary diets of the main restaurant of University of São Paulo (COSEAS) - (RH and RHS) used in biological assay ${ }^{1,2}$.

\begin{tabular}{llll}
\hline \multicolumn{1}{c}{ Composition } & \multicolumn{2}{c}{ Groups } \\
& & $\mathrm{RC}^{\mathbf{3}}$ & $\mathrm{RCS}^{4}$ \\
\hline Energy & $\mathrm{Kcal}$ & $374.8^{\mathbf{a}}$ & $370.89^{\mathbf{a}}$ \\
Energy & $\mathrm{Kj}$ & $1567^{\mathbf{a}}$ & $1550^{\mathbf{a}}$ \\
Moisture & $\%$ & $10.45(1.38)^{\mathbf{a}}$ & $10.77(1.71)^{\mathbf{a}}$ \\
Protein & $\%$ & $16.35(1.84)^{\mathbf{a}}$ & $16.55(2.13)^{\mathbf{a}}$ \\
Lipids & $\%$ & $11.00(1.87)^{\mathbf{a}}$ & $11.17(2.21)^{\mathbf{a}}$ \\
Carbohydrates & $\%$ & $52.60^{\mathbf{a}}$ & $51.04^{\mathbf{a}}$ \\
Total Fiber & $\%$ & $6.10^{(5)} \mathbf{a}$ & $6.20^{(5)} \mathbf{a}$ \\
Total Mineral & $\%$ & $3.50(0.27)^{\mathbf{a}}$ & $4.27(0.43)^{\mathbf{b}}$ \\
Zinc (Zn) & $\mathrm{mg} / \mathrm{kg}$ & $26.27(0.88)^{\mathbf{a}}$ & $60.63(1.28)^{\mathbf{b}}$ \\
Copper $(\mathrm{Cu})$ & $\mathrm{mg} / \mathrm{kg}$ & $2.35(0.06)^{\mathbf{a}}$ & $2.19(0.04)^{\mathbf{a}}$ \\
& & & \\
\hline
\end{tabular}

(1) Values represent mean \pm S.D. of 3 determinations per sample.

(2) In each line the different superscript values are significantly different from each other at $\mathrm{p}<0,05$.

(3) $\mathrm{RH}$-Customary Diet of the main restaurant of University of São Paulo (COSEAS) - non-supplemented.

(4) RHS - Customary Diet of the main restaurant of University of São Paulo (COSEAS) - supplemented with zinc ( $\mathrm{Zn})$.

${ }^{\text {(5) }}$ Calculated by estimative of cellulose adedded.

Non-supplemented groups showed an average of 9 for $\mathrm{Zn} / \mathrm{Cu}$ ratio, whereas supplemented groups reached an average of 20, for the same ratio. The animals of RHS group showed a substantially higher $\mathrm{Zn} / \mathrm{Cu}$ ratio of 25.37, which may indicate that copper absorption could be impaired (Oestreicher \& Cousins, 1985; Couzy et al., 1993). However, no consequences were detected on animal weight gain or diet consumption. The same results were obtained in the experiment of Reeves (1996), which studied the influence of factors present in the AIN 93G diet on nutritional status relating to copper, in animals under zinc supplementation.

Concentration and total amount of metallothionein were determined in three tissues where zinc has an important metabolic or regulatory role (Table 3).

The data obtained for metallothionein concentration in liver and kidneys are similar to those found by Chen et al. (1995). The comparison between groups detected no significant differences ( $p>0.05)$, whatever the relation between liver, kidneys or testes of animals from groups RC and RCS, and between RH and RHS, regarding metallothionein concentrations, as a response to zinc supplementation.

Liver, kidneys and testes show significant different concentrations and total amounts of metallothionein $(p<0.05)$ when compared to the averages of the same variables in the tissues under analysis. The liver showed higher concentrations than testes and kidneys $(p<0.05)$, regardless of the diet consumed by the animals.

Different effects were observed in the data 
Table 3. Metallothionein - MT concentration $(\mu \mathbf{g} / \mathbf{g}$ of tissue) and total metallothionein - MT $(\mu \mathbf{g})$ in livers, kidneys and testes of rats fed diets with different concentrations of zinc (Zn) in groups fed AIN 93G- like diets (RC and RCS) and customary diets of the main restaurant of University of São Paulo (COSEAS) - (RH and RHS) ${ }^{1,2,3}$.

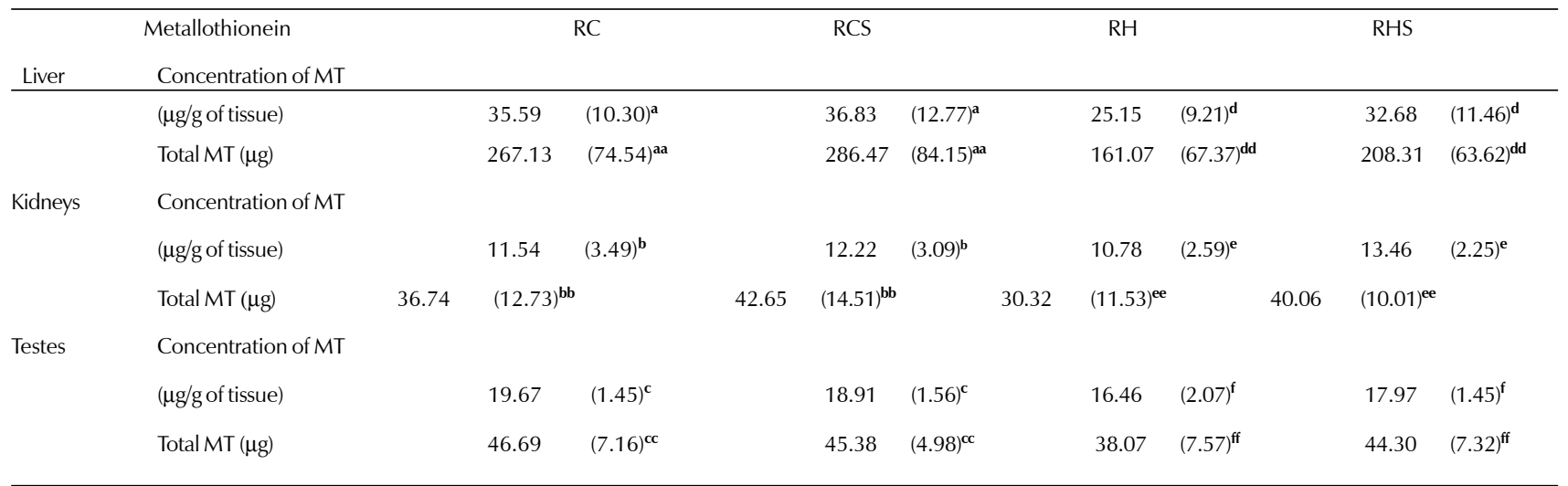

${ }^{(1)}$ Values represent mean \pm S.D. of 8 rats per treatment group.

${ }^{(2)}$ In each column the different superscript values are significantly different from each other at $\mathrm{p}<0.05$.

${ }^{(3)}$ In each line the different superscript values are significantly different from each other at $\mathrm{p}<0.05$ (always RC vs. RCS and RH vs. RHS).

${ }^{(3)}$ Random errors: Liver: RC 1.61\%, RCS 1.62\%; Kidneys: RC 2.57\%, RCS 2.83\%; Testes: RC 2.18\%, RCS $1.67 \%$. Liver: RH $2.35 \%$, RHS $1.93 \%$; Kidneys: RH $3.12 \%$, RHS $3.24 \%$; Testes: RH $1.70 \%$, RHS $1.63 \%$.

Table 4. Mean and standard deviation of the concentrations of Zinc ( $\mu \mathrm{g} / \mathrm{g}$ of tissue) and total Zinc ( $\mu \mathrm{g})$ in livers, femures, kidneys and testes in groups fed with AIN 93G like diets (RC and RCS) and with customary diets of the main restaurant of University of São Paulo (COSEAS) - (RH and RHS) ${ }^{1,2,3}$.

\begin{tabular}{|c|c|c|c|c|c|c|c|c|c|}
\hline \multirow[b]{2}{*}{ Liver } & \multicolumn{2}{|l|}{ Zinc } & \multirow[t]{2}{*}{$\mathrm{RC}$} & \multicolumn{2}{|c|}{ RCS } & \multicolumn{2}{|l|}{$\mathrm{RH}$} & \multicolumn{2}{|c|}{ RHS } \\
\hline & Concentration of Zinc & & & & & & & & \\
\hline & ( $\mu \mathrm{g} / \mathrm{g}$ of tissue) & 35.49 & $(2.12)^{\mathbf{a}}$ & 38.94 & $(3.43)^{\mathbf{b}}$ & 39.46 & $(2.58)^{\mathrm{g}}$ & 42.83 & $(2.78)^{h}$ \\
\hline & Total Zinc $(\mu \mathrm{g})$ & 271.94 & $(18.25)^{\mathrm{aa}}$ & 296.20 & $(37.14)^{\mathbf{b b}}$ & 237.08 & $(21.42)^{\mathrm{gg}}$ & 268.28 & $(20.51)^{\mathrm{hh}}$ \\
\hline \multirow[t]{3}{*}{ Femurs } & Concentration of Zinc & & & & & & & & \\
\hline & ( $\mu \mathrm{g} / \mathrm{g}$ of tissue) & 127.97 & $(6.36)^{\mathbf{b}}$ & 140.04 & $(6.03)^{\mathbf{c}}$ & 45.49 & $(1.75)^{\mathbf{i}}$ & 86.57 & $(6.95)^{\mathbf{j}}$ \\
\hline & Total Zinc $(\mu \mathrm{g})$ & 83.79 & $(7.17)^{\mathbf{b b}}$ & 97.45 & $(7.25)^{\mathbf{c c}}$ & 18.77 & $(1.29)^{\mathrm{ii}}$ & 36.00 & $(4.33) \mathrm{ji}$ \\
\hline \multirow[t]{3}{*}{ Kidneys } & Concentration of Zinc & & & & & & & & \\
\hline & ( $\mu \mathrm{g} / \mathrm{g}$ of tissue) & 27.72 & $(1.90)^{d}$ & 28.26 & $(2.27)^{\mathbf{d}}$ & 26.95 & $(1.31)^{\mathbf{k}}$ & 27.81 & $(1.71)^{k}$ \\
\hline & Total Zinc $(\mu \mathrm{g})$ & 46.60 & $(6.34)^{\text {dd }}$ & 49.08 & $(7.49)^{\text {dd }}$ & 32.13 & $(3.86)^{\mathbf{k k}}$ & 32.42 & $(4.59)^{\mathbf{k k}}$ \\
\hline \multirow[t]{3}{*}{ Testis } & Concentration of Zinc & & & & & & & & \\
\hline & ( $\mu \mathrm{g} / \mathrm{g}$ of tissue) & 25.69 & $(1.32)^{\mathbf{e}}$ & 23.92 & $(0.55)^{\mathrm{f}}$ & 27.86 & $(1.29)^{l}$ & 27.79 & $(1.67)^{I}$ \\
\hline & Total Zinc $(\mu \mathrm{g})$ & 33.13 & $(2.99)^{\mathbf{e e}}$ & 29.31 & $(1.97)^{\mathrm{ff}}$ & 34.31 & $(3.53)^{\mathrm{II}}$ & 35.64 & $(5.97)^{I I}$ \\
\hline
\end{tabular}

${ }^{(1)}$ Values represent mean \pm S.D. of 8 rats per treatment group.

${ }^{(2)}$ In each column the different superscript values are significantly different from each other at $\mathrm{p}<0.05$.

${ }^{(3)}$ In each line the different superscript values are significantly different from each other at $\mathrm{p}<0.05$ (always RC vs. RCS and RH vs. RHS).

analyses for metallothionein concentration in relation to zinc, in each tissue. A direct correlation between an increase in zinc concentration in tissue and an increase in metallothionein level, as a response to zinc supplementation, could only be established for the liver. The relationship is more accurately observed when the intergroup effect is removed, leading to a significant correlation between the variables under study in the $\mathrm{RH}$ group $(p<0.05, r=0.65)$. For testes, the same effect was observed for the residual concentration of zinc on the level of metallothionein, when the comparison was made in supplemented groups. In contrast, without taking the intergroup effect into consideration, that is, submitting each group to individual analysis, a significant correlation was observed for the non-supplemented RC group $(p<0.05, r=0.60)$.

Liver and femurs are tissues which clearly reflect the effect of zinc supplementation (Table 4). Significant differences $(p<0.05)$ between supplemented and non-supplemented groups were found for the tissues, regardless of the diet consumed (RC vs RCS, and RH vs RHS). Femurs, 
particularly from the RHS group, showed almost twice the $\mathrm{Zn}$ concentration of that of the $\mathrm{RH}$ group, explaining the high responsiveness of the tissue in face of $\mathrm{Zn}$ supplementation, in relation to zinc concentration parameter.

Liver tissue plays a main role in the metabolism of the mineral, metalloproteins and of metalloenzymes zinc-dependent, largely described by Pattison \& Cousins (1986). Zinc liver concentrations in animals of groups $\mathrm{RH}$ and RHS showed an increase in direct proportion to the increase in weight gain $(p<0.05, r=0.57)$. The same relationship can be observed for femurs of animals of the same groups $(p<0.05, r=0.55)$. An identical effect was observed for kidneys only when comparing groups RC and RCS. No significant correlation between weight gain and zinc concentration was observed in the testes.

Different diet compositions may influence zinc distribution if a correlation is established between zinc consumption and concentration of the mineral in different tissues. Femurs from animals of groups RC and RCS follow a standard that is quite characteristic in relation to supplementation, in which tissue zinc concentration increases with increasing zinc consumption $(p<0.05, r=0.62)$. The same effect was not observed in groups $\mathrm{RH}$ and RHS ( $p>0.05, r=0.39)$ in which the low values obtained for zinc concentration and total zinc could represent a mobilization of mineral stores to other body tissues.

A correlation between the consumption of $\mathrm{Zn}$ and total content of metallothionein shows a significant result only in the liver of animals of groups RC and RHS $(p<0.05, r=0.79$ and $r=0.74)$, possibly as a result of zinc homeostasis in the tissue, since the animals fed casein diet (AIN 93G) show no response to $\mathrm{Zn}$ supplementation, whereas the animals fed the diet of the main restaurant showed a discrete correlation between zinc consumption and total amount of hepatic metallothionein. Total liver $\mathrm{MT} / \mathrm{Zn}$ ratio is significantly higher in supplemented than in non-supplemented groups, meaning that the diet of the restaurant gave rise to a greater response than the AIN 93-like diet, considering the parameters under study.

The results indicate that a steady metallothionein concentration is attained, whether the animals are supplemented or not, and regardless of zinc food matrix. This is partially in accordance with the findings of Reeves (1995), who concluded that periods greater than fifteen days of $\mathrm{Zn}$ supplementation resulted in an adaptive metabolism response towards metallothioneins. The result means a change from a period of intense synthesis during the two first weeks, to basal levels stabilized during the following weeks.

Total liver metallothionein is almost five times greater than kidney and testes MT. Liver concentration doubles that found in the other tissues under analyses, in accordance with the tendency observed when zinc liver concentrations were recorded. The fact shows not only the importance of liver in $\mathrm{Zn}$ and metalloprotein metabolism, but also proves that the considerable volume of the organ is not the only factor responsible for the very high rate of metallothionein synthesis.

The concentrations of metallothionein determined in testes were quite high, if it is taken into account the substantially small volume of the organ. The finding is consistent with the expected high average concentrations of zinc in the testes, and highlights the importance of the same metal in the physiology of male reproductive system. The same subject was formerly approached by other authors, such as Gilabert et al. (1996), who studied zinc-deficient rats and pointed to a decrease in $\mathrm{Zn}$ content in testis and in the weight of the organ, in addition to morphological changes in seminal vesicle and prostate when compared to the control group. More recent studies (Reeves \& Rossow 1993) showed the importance of zinc fixation in testes to maintain the catalytic function of the Angiotensin Converting Enzyme (ACE), which has an atom of $\mathrm{Zn}$ in its coordination site. Some speculation was put forward about a possible main role of metallothionein in zinc fixation, similar to the mechanism proposed by Hempe \& Cousins (1992), involving metallothionein and cysteine-rich proteins of the small intestine (CRIP).

In conclusion, zinc supplementation, in the amounts and for the period of time under study, brought no change to the metallothionein profile in the three tissues where zinc concentrations were determined. The results suggest an accordance with the theory of adaptive response to metallothionein metabolism after a certain supplementation period. Zinc carried by different food matrices showed a slight change in mineral levels in the tissues assayed. Liver and femurs are tissues responsive to zinc oral supplementation, since significant increases in zinc concentrations and total amounts were detected in animals supplemented with the metal. The findings point to a tendency towards zinc distribution in the body between metabolically active tissues and those for store of the metal. On the contrary, the concentration of metallothioneins, with levels significantly higher in the liver of the animals under study, confirm its role as a central organ in zinc metabolism and metalloprotein sites, whereas the levels in testes presuppose the importance of mobilization and bioavailability of zinc to tissues of the reproductive system of young male rats. In the present study, although the degree of responsiveness observed for metallothionein synthesis is low, the results for zinc tissue concentration remain valid, suggesting different degrees for zinc bioavailability and greater responsiveness for the customary diet from the main restaurant as compared to the AIN 93 like-diet, in relation to the parameters under assay.

\section{REFERENCES}

BREMNER, I., BEATTIE, J.H. Metallothionein and the trace minerals. Annual Review of Nutrition, Palo Alto, v.10, p.63-83,1990. 
CAI, L., SATOH, M., TOHYAMA, C., CHERIAN, M.G. Metallothionein in radiation exposure: its induction and protective role. Toxicology, New York, v.132, n.2-3, p.85-98, 1999.

CAI, L., DENG, D.X., JIANG, J., CHEM, S., ZHONG, R. CHERIAN, M.G., CHAKRABARTI, S. Induction of metallothionein synthesis with preservation of testicular function in rats following long term renal transplantation. Urological Research, New York, v.28, n.2, p.97-103, 2000.

CHEN, Y., SAARI, J.T., KANG, J. Copper deficiency increases metallothionein -I mRNA content selectively in rat liver. Journal of Nutritional Biochemistry, Stoneham, v.6, n.11, p.572-576, 1995

CHMIELNICKA, J., SOWA, B. Variations in metallothionein, Zn, $\mathrm{Cu}$ and Fe concentrations and ceruloplasmin activity in pregnant rat dams and their fetuses. Ecotoxicol Environ Saf, New York, v.46, n.2, p.130-136, 2000.

COUZY, F., KEEN, C., GERSHWIN, M.E., MARESCHI, J.P. Nutritional implications of the interactions between minerals. Progress Food and Nutrition Science, Oxford, v.17, n.1, p.6587, 1993.

COZZOLINO, S.M.F. Biodisponibilidade de minerais. Revista de Nutrição da PUCCAMP, Campinas, v.10, n.2, p.87-98, 1997.

EATON, D.L., CHERIAN, M.G. Determination of metallothionein in tissues by cadmium-hemoglobin affinity assay. Methods in Enzymology, New York, v.205, p.83-88, 1991.

GILABERT, E.R., RUIZ, E., OSORIO, C., ORTEGA, E. Effect of dietary zinc deficiency on reproductive function in male rats: Biochemical and morphometric parameters. Journal of Nutritional Biochemistry, Stoneham, v.7, n.7, p.403-407, 1996.

HEMPE, J.M., COUSINS, R.J. Cystein-rich intestinal protein and intestinal metallothionein: an inverse relationship as a conceptual model for zinc absorption in rats. Journal of Nutrition, Philadelphia, v.122, n.1, p.89-95, 1992.

HOADLEY, J.E., LEINART, A.S., COUSINS, R.J. Kinetic analysis of zinc uptake and serosal transfer by vascularly perfused rat intestine. American Journal of Physiology, Bethesda, v.252, n.1, p.G825-G831, 1987.

JACOB, S.T., GHOSHAC, K., SHERIDAN, J.F. Induction of metallothionein by stress and its molecular mechanism. Gene Expression, North Chicago, v.7, n.4-6, p.301-310, 1999.

LAU, J.C, CHERIAN, M.G. Developmental changes in hepatic metallothionein, zinc and copper levels in genetically altered mice. Biochemistry and Cell Biology, Ottawa, v.76, n.4, p.615-
623, 1999.

OESTREICHER, P., COUSINS, R.J. Copper and zinc absorption in the rat: mechanism of mutual antagonism. Journal of Nutrition, Philadelphia, v.115, n.2, p.159-166, 1985.

PATTINSON, S.E., COUSINS, R.J. Zinc uptake and metabolism by hepatocytes. Fed Proc, Washington DC, v. 45 , n.12, p.2805-2809, 1986.

REEVES, P.G., ROSSOW, K.L. Zinc deficiency affects the activity and protein concentration of angiotensin-converting enzyme in rat testes. Proceedings Society of the Experimental for Biology and Medicine, New York, v.203, n.3, p.336-342, 1993.

REEVES, P.G. Adaptation responses in rats to long-term feeding of high-zinc diets: emphasis on intestinal metallothionein. Journal of Nutritional Biochemistry, Stoneham, v.6, n.1, p.4854, 1995.

REEVES, P.G. Copper status of adult male rats is not affected by feeding an AIN 93G-based diet containing high concentrations of zinc. Journal of Nutritional Biochemistry, Stoneham, v.7, n.3, p.166-172, 1996.

RIPA, S., RIPA, R. Metallothionein. Bollettino Chimico Farmaceutico, Milano, v.138, n.2, p.1S-18S, 1999. Supplement.

TRAN, C.D., BUTLER, R.N., HOWARTH, G.S., PHILCOX, J.C., ROFE, A.M., COYLE, P. Regional distribution and localization of zinc and metallothionein in the intestine of rats fed diets differing in zinc content. Scandinavian Journal of Gastroenterology, Oslo, v.34, n.7, p. 689-695, 1999.

VALLEE, B.L., COLEMAN, J.E., AULD, D.S. Zinc fingers, zinc clusters and zinc twists in DNA-binding protein domains. Proceedings of the National Academy of Sciences of USA, Washington DC, v.88, n.3, p.999-1003, 1991.

VALLEE, B.L., FALCHUK, K.H. The biochemical basis of zinc physiology. Physiological Reviews, Bethesda, v.73, p.79-118, 1993.

VALLES MOTA, J.P., LANDE ARIAS, A.R., FERNANDEZ DE LA CAMPA, M.R., GARCIA ALONSO, J.I. Development of a stable isotope approach for the inductively coupled plasma-mass spectrometry determination of oxidized metallothionein in biological materials. Analytical Biochemistry, Baltimore, v.282, n.2, p.194-199, 2000.

Recebido para publicação em 9 de dezembro de 1999 e aceito em 4 de outubro de 2000. 